\title{
Biodegradation and Detoxification of Congo Red by Intuitive Bacterial Strain TVU-CR4
}

\author{
A. Barathi ${ }^{1}$, J. Hemapriya ${ }^{1}$, Ramya Gunasekaran ${ }^{2}$, Kayeen Vadakkan ${ }^{3}$, \\ A. Shyamala ${ }^{4}$, Aswini Ravi ${ }^{5}$ and S. Vijayanand ${ }^{2 *}$
}

\author{
${ }^{1}$ Department of Microbiology, DKM College, Vellore, Tamilnadu, India \\ ${ }^{2}$ Department of Biotechnology, Thiruvalluvar University, Vellore, Tamilnadu, India \\ ${ }^{3}$ Department of Biotechnology, Sri Sankara College, Kanchipuram, Tamilnadu, India \\ ${ }^{4}$ Department of Biotechnology, St. Mary's College, Thrissur, Kerala, India \\ ${ }^{5}$ Department of Biotechnology, DKM College, Chennai, Tamilnadu, India
}

*Corresponding author

\section{A B S T R A C T}

\section{Keywords}

Congo red,

Detoxification,

Macrotyloma

uniflorum,

Phytotoxicity,

Textile azodye

Article Info

Accepted:

25 October 2020

Available Online:

10 November 2020
Environmental pollution has been renowned as one of the foremost problems of the modern world. Ever-increasing industrialization and urbanization result in the discharge of hazardous waste to the environment, which in turn creates more pollution. Environmental biotechnology is persistently intensifying its efforts in the biological treatment of colored textile effluents, which is an environmental friendly and low cost alternative to physicochemical processes. In the present study, effluent samples were collected from various textile and dyeing industries located in and around Vellore District, Tamilnadu, India and were exploited for the screening and isolation of bacterial strains that were capable of decolorizing Congo red. Optimization of cultural conditions was carried out to maximize decolorization efficiency of the bacterial isolate TVU-CR4 towards Congo red. Decolorization efficiency was found to be optimized at $35^{\circ} \mathrm{C}$, neutral $\mathrm{pH}$, after $24 \mathrm{~h}$ of incubation. Static conditions proved to be effective in maximizing decolorization. Increase in dye concentration decreased decolorization efficiency of TVU-CR4. Among the various carbon and nitrogen sources investigated; glucose and yeast extract instigated maximum decolorization. Detoxification was confirmed by phytotoxicity assay using Macrotyloma uniflorum.

\section{Introduction}

William Henry Perkin in 1856, accidently discovered the world's first commercially successful synthetic dye and named it as 'Mauveine'. Since then, more than 1, 00,000 new synthetic dyes have been generated (Hemapriya and Vijayanand, 2014). Synthetic dyes are colored substances that color fibers permanently, without losing its color even when exposed to sweat, sunlight, water and many chemical substances including oxidizing agents and also to microbial attack (Rai et al., 2005; Saratale et al., 2011). These dyes were used in different industries, with an annual consumption of about 0.7 million tons 
worldwide. Synthetic dyes were extensively used in many fields of upto date technology, for example in various branches of the textile industry, in leather tanning industry, in paper production, in food industries, in agricultural research, in cosmetic industry, in light harvesting arrays, and in photoelectrochemical cells (Hemapriya and Vijayanand, 2013). Of the approximately $10^{9}$ $\mathrm{kg}$ of dyestuffs estimated to be manufactured annually throughout the World, the two most widely used in the textile industry are the azo and anthraquin one groups (Križanec and Marechal, 2006; Forss, 2011). Nearly all the dyestuffs used by the textile industry are azo dyes.

Global extension of textile industry has led to an alarming expansion in the utilization of such synthetic dyestuffs, resulting in a rise in environmental pollution due to the contamination of effluents (Pandey et al., 2007; Shyamala et al., 2014). In addition to the unpleasant appearance of the textile industries wastewater, the disposal of these untreated effluent waters into natural receiving waters causes damage to the environment as they significantly affect the photosynthetic activity in aquatic life due to reduced sunlight penetration and may also be toxic to aquatic flora and fauna due to the presence of hazardous metals, chlorides etc. and the breakdown products of dyes in them (Cetin and Donmez, 2006; Fan et al., 2009, Vijayanand et al., 2017).

Environmental pollution has been renowned as one of the foremost problems of the modern world. The escalating demand for water and the deteriorating supply has made the treatment and reuse of industrial effluents as an attractive option.

Therefore treatment of industrial effluent containing aromatic compounds becomes necessary prior to their final discharge into the environment (Shyamala et al., 2014). Moreover, the frequently high volumetric rate of industrial effluent discharge in combination with increasingly stringent legislation, make the search for appropriate treatment technologies an important priority. So, necessitate of efficient and economic processes to treat these effluents have become an alarming concern. As a consequence, there has been a mounting interest in biotechnological processes.

Implementation of different physico-chemical techniques including coagulation/ flocculation, membrane filtration, ultrasonic mineralization, precipitation, floatation, adsorption, ion exchange, ion pair extraction, electrolysis, advanced oxidation process (chlorination, bleaching, ozonation, Fenton's oxidation and photo catalytic oxidation) and chemical reduction have inbuilt drawbacks of being economically unfeasible (more energy consumption and chemical uses), unable to remove the recalcitrant azo dyes and/or their organic metabolites completely, generating a significant amount of sludge that may cause secondary pollution problems (Anjaneyulu et al., 2005; Vijayanand and Hemapriya., 2013).

The microbial decolorization and degradation of synthetic dyes has been of considerable interest since it is inexpensive, eco-friendly and produces a less amount of sludge (Kalyani et al., 2009).

Thus, the present study investigates the efficacy of textile effluent adapted bacterial strain to mediate biodecolorization and biodegradation of Congo red.

The optimal cultural conditions for maximizing biodecolorization was studied and further detoxification were investigated by phytotoxicity study using Macrotyloma uniflorum. 


\section{Materials and Methods}

\section{Sample Collection and Physico-chemical analysis}

The effluent samples was collected from both textile industries and dyeing units located in and around Vellore District. Tamil Nadu, India. Samples were collected at the surface and at various depths (S1, S2 and S3) and were placed in sterile polythene bags.

\section{Dye stuff used}

Synthetic textile azo dye, Congo red used for this study was procured from a local textile dyeing unit. Stock solution was prepared by dissolving $1 \mathrm{~g}$ of Congo red in $100 \mathrm{ml}$ distilled water. All chemicals used were of the highest purity available and of an analytical grade.

\section{Enrichment and screening of bacterial strains decolorizing Congo red}

The textile effluent samples were serially diluted and plated onto the surface of Nutrient agar medium enriched with $50 \mathrm{ppm}$ of Congo red. $\mathrm{pH}$ was adjusted to 7.0 before autoclaving and incubated at $37^{\circ} \mathrm{C}$ for 5 days. Colonies surrounded by halo (decolorized) zones were picked and streaked on Nutrient agar medium containing dyestuff. The plates were reincubated at $37^{\circ} \mathrm{C}$ for 3 days to confirm their abilities to decolorize Congo red. Morphologically distinct colonies of dye decolorizing bacteria were selected and restreaked several times to obtain pure cultures.

\section{Decolorization assay}

A loopful of the selected bacterial culture was inoculated in Erlenmeyer flask containing 100 $\mathrm{ml}$ of nutrient broth and incubated at $150 \mathrm{rpm}$ at $37^{\circ} \mathrm{C}$ for $24 \mathrm{~h}$. Then, $1 \mathrm{ml}$ of overnight broth culture of the bacterial strain was inoculated in $100 \mathrm{ml}$ of nutrient broth containing $50 \mathrm{ppm}$ of Congo red and reincubated at $37^{\circ} \mathrm{C}$ till complete decolorization occurs.

Suitable control without any bacterial culture was also run along with experimental flasks. $1.0 \mathrm{ml}$ of sample was withdrawn every $12 \mathrm{~h}$ and centrifuged at $10,000 \mathrm{rpm}$ for $15 \mathrm{~min}$. Decolorization extent was determined by measuring the absorbance of the culture supernatant at $500 \mathrm{~nm}$ using UV-visible spectrophotometer, according to Shyamala et al., (2014).

Decolorization efficiency $(\%)=$ Dye $(\mathrm{i})-$ Dye (r) / Dye (i) X 100

Where, Dye (i) refers to the initial dye concentration, Dye (r) refers to the residual dye concentration. Decolorization experiments were performed in triplicates.

\section{Optimization of culture conditions for biodecolorization of Congo red}

\section{Effect of incubation time, temperature, $\mathrm{pH}$, agitation rates and dye concentration}

Optimization of culture conditions for decolorization of Congo red was carried out by incubating the bacterial strain at different temperatures $\left(20-50^{\circ} \mathrm{C}\right)$, different $\mathrm{pH}$ values of the medium ( $\mathrm{pH}$ 4.0-10.0), different agitation speeds $(0-200 \mathrm{rpm})$ and various dye concentrations (200-1000 ppm).

\section{Effect of carbon and nitrogen sources}

The effect of various soluble carbon sources $(1 \% \mathrm{w} / \mathrm{v})$ (glucose, sucrose, lactose, maltose, starch) and nitrogen sources (tryptone, beef extract, peptone, yeast extract and meat extract) on dye decolorization extent of Congo red by bacterial strain TVU-CR4, was investigated. 


\section{Phytotoxicity studies}

Phytotoxicity tests were performed in order to assess the toxicity of the untreated and treated dye samples. The ethyl acetate extracted products of degraded azo dyes were dried and dissolved in $5 \mathrm{ml}$ sterile distilled water to make a final concentration of $100 \mathrm{ppm}$. Phytotoxicity tests were carried out on Macrotyloma uniflorum. 10 healthy plant seeds were treated separately with $5 \mathrm{ml}$ of control dye and degraded products respectively/per day. Control sets were carried out using distilled water at the same time. Germination percentage as well as the length of plumule and radical was recorded after 7 days (Saratale et al., 2009; Shyamala et al., 2014).

\section{Results and Discussion}

Ever increasing demand for water and the dwindling supply has made the treatment and reuse of industrial effluents as an attractive option. Textile industries consume a considerable amount of water in their manufacturing processes. Considering both the volume and the effluent composition, the textile industry is rated as the most polluting among the industrial sectors.

Textile effluents are of global concern because they color the drains and ultimately the receiving water bodies (Olukanni et al., 2006; Hemapriya and Vijayanand, 2013). In view of the need for a technically and economically satisfying treatment technology, a flurry of emerging technologies are being proposed and tested at different stages of commercialization.

Broader validation of these new technologies and integration of different methods in the current treatment schemes will most likely in the near future, render these both efficient and economically viable (Goncalves et al., 2000).
Isolation and screening of bacterial strains decolorizing Congo red

Eight morphologically distinct bacterial isolates, designated as TVU-CR1 to TVUCR8 that was capable of decolorizing Congo red were isolated from different effluent samples. Among the above mentioned isolates, TVU-CR4 isolate was found to be the efficient bacterial strain exhibiting maximum decolorization efficiency (92\%) (Table 1), which was selected for the further studies. Similarly many bacterial strains were reported to decolorize textile azo dyes (Deng et al., 2008; Hemapriya et al., 2010; Vijayanand et al., 2017)

Optimization of culture conditions for maximizing decolorizing ability of TVUCR4

\section{Effect of incubation time}

Results of the present study revealed that the dye decolorizing ability of the isolate was dependent on the bacterial growth. The dye decolorization process started after $4 \mathrm{~h}$ and reached its maximum level within $24 \mathrm{~h}$ and thereafter started to decline, due to the depletion of nutrients and accumulation of toxic metabolites, which inhibit the multiplication of the bacterial isolate (Fig 1). Similarly, Decolorization of Evan's Blue by E.coli strain AKI-2 was achieved after $24 \mathrm{~h}$ of incubation (Aswinkumar et al., 2017). In contrast, decolorization of Methyl orange by Bacillus sp. strain TVU-M4 was achieved after $32 \mathrm{~h}$ of incubation (Shyamala et al., 2014).

\section{Effect of temperature}

Color removal efficiency of the bacterial strain TVUBK-04 increased with increase in incubation temperature, reaching highest levels between $30-40^{\circ} \mathrm{C}$, with optimum being 
$35^{\circ} \mathrm{C}$ after $24 \mathrm{~h}$ of incubation, indicating that the decolorization process was directly proportional to the increase in incubation temperature. Decolorization activity was significantly suppressed at temperatures more than $40^{\circ} \mathrm{C}$, which might be due to the loss of cell viability or denaturation of the enzymes responsible for the decolorization at elevated temperatures (Cetin and Donmez, 2006; Carvalho et al., 2008). Interestingly, the Decolorization percentage was found to be reduced at temperatures below $30^{\circ} \mathrm{C}$.

\section{Effect of pH}

Dye decolorization efficiency of the bacterial strain TVU-CR4 was detected over a broad range of $\mathrm{pH}$ (5.0-9.0), with optimum decolorization being exhibited at neutral $\mathrm{pH}$
(7.0). $\mathrm{pH}$ tolerance of the decolorizing bacteria is quite important because the reactive azo dyes bind to cotton fibers by the addition or substitution mechanisms under alkaline conditions (Aksu et al., 2007). However, incubation at both acidic and alkaline $\mathrm{pH}$ slightly reduced the dye decolorization efficiency of the bacterial strain TVU-CR4 (Fig 3). Pure cultures of Proteus vulgaris NCIM-2027 and Micrococcus glutamicus NCIM-2168 showed maximum decolorization efficiency at neutral pH (7.0) (Saratale et al., 2009). In contrast, optimal $\mathrm{pH}$ values for the decolorization of Reactive Red RB by a microbial consortium and Acid orange by a halophilic bacterial consortium was found to be 8.0 (Cetin and Donmez, 2006; Vijayanand et al., 2017)..

Table.1 Bacterial Strains Decolorizing Congo red under Aerobic Conditions

\begin{tabular}{|c|c|c|c|c|}
\hline $\begin{array}{c}\text { Sl. } \\
\text { No }\end{array}$ & Isolates & $\begin{array}{c}\text { Sample } \\
\text { Collection Site }\end{array}$ & $\begin{array}{c}\text { Time taken for } \\
\text { Maximum } \\
\text { Decolorization }\end{array}$ & $\begin{array}{c}\text { Decolorization } \\
\text { Efficiency }\end{array}$ \\
\hline $\mathbf{1}$ & TVU-CR1 & $\mathrm{S} 1$ & $60 \mathrm{~h}$ & $64 \%$ \\
\hline $\mathbf{2}$ & TVU-CR2 & $\mathrm{S} 3$ & $48 \mathrm{~h}$ & $60 \%$ \\
\hline $\mathbf{3}$ & TVU-CR3 & $\mathrm{S} 1$ & $60 \mathrm{~h}$ & $74 \%$ \\
\hline $\mathbf{4}$ & TVU-CR4 & $\mathrm{S} 2$ & $24 \mathrm{~h}$ & $92 \%$ \\
\hline $\mathbf{5}$ & TVU-CR5 & $\mathrm{S} 3$ & $60 \mathrm{~h}$ & $71 \%$ \\
\hline $\mathbf{6}$ & TVU-CR6 & $\mathrm{S} 2$ & $36 \mathrm{~h}$ & $79 \%$ \\
\hline $\mathbf{7}$ & TVU-CR7 & $\mathrm{S} 1$ & $72 \mathrm{~h}$ & $81 \%$ \\
\hline $\mathbf{8}$ & TVU-CR8 & $\mathrm{S} 3$ & $36 \mathrm{~h}$ & $69 \%$ \\
\hline
\end{tabular}

Note: The isolates were considered for the table that showed above 50\% decolorization ability

Table.2 Effect of Carbon Sources on Decolorization Efficiency of TVU-CR4

\begin{tabular}{|c|c|c|}
\hline S.No & Carbon Source $\left.\mathbf{~ ( g l}^{\mathbf{- 1}}\right)$ & Decolorization $\%$ \\
\hline $\mathbf{1 .}$ & Glucose & $92 \pm 0.02$ \\
\hline $\mathbf{2 .}$ & Sucrose & $89 \pm 0.04$ \\
\hline $\mathbf{3 .}$ & Lactose & $84 \pm 0.05$ \\
\hline $\mathbf{4 .}$ & Maltose & $78 \pm 0.04$ \\
\hline $\mathbf{5 .}$ & Starch & $74 \pm 0.02$ \\
\hline
\end{tabular}


Table.3 Effect of Nitrogen Sources on Decolorization Efficiency of TVU-CR4

\begin{tabular}{|c|c|c|}
\hline S.No & Nitrogen Source $\mathbf{~ ( g l}^{\mathbf{-}} \mathbf{)}$ & Decolorization $\%$ \\
\hline 1. & Peptone & $76 \pm 0.03$ \\
\hline 2. & Yeast Extract & $92 \pm 0.04$ \\
\hline 3. & Tryptone & $82 \pm 0.02$ \\
\hline 4. & Beef Extract & $88 \pm 0.06$ \\
\hline
\end{tabular}

Table.4 Phytotoxicity Study of Congo red and its Degradation Products on M. uniflorum

\begin{tabular}{|c|c|c|c|c|}
\hline S.No & Parameters Studied & Tap water & Congo red & Treated sample \\
\hline 1. & Germination \% & 100 & 60 & 100 \\
\hline 2. & Plumule $(\mathrm{cm})$ & $22 \pm 0.7$ & $12 \pm 0.4$ & $21 \pm 0.5$ \\
\hline 3. & Radical $(\mathrm{cm})$ & $8 \pm 0.6$ & $5 \pm 0.5$ & $7.5 \pm 0.4$ \\
\hline
\end{tabular}

Fig.1 Effect of incubation time on the decolorization of Congo red by TVU-CR4

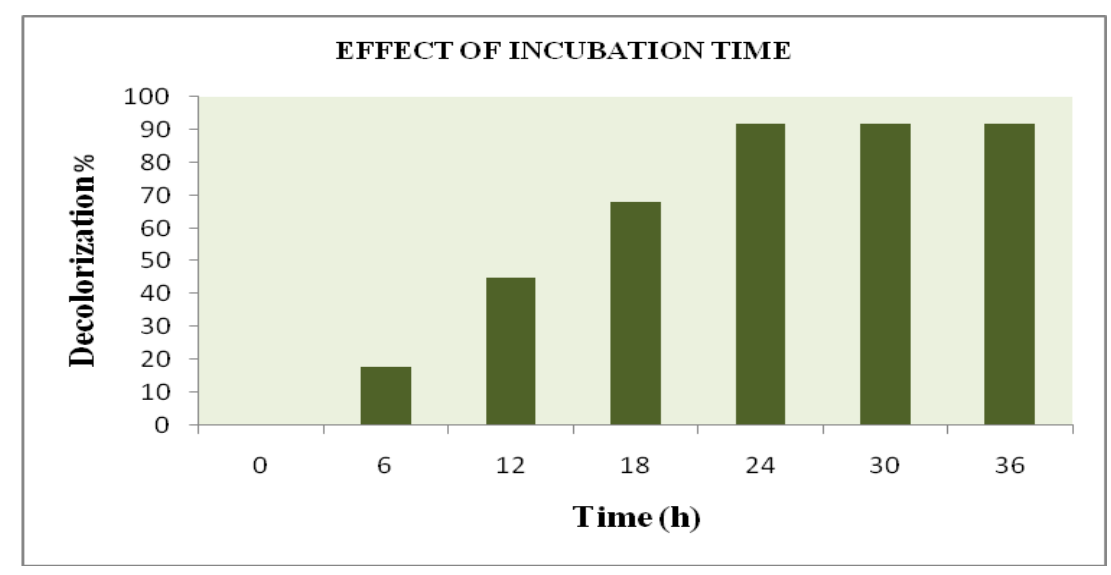

Fig.2 Effect of temperature on the decolorization of Congo red by TVU-CR4

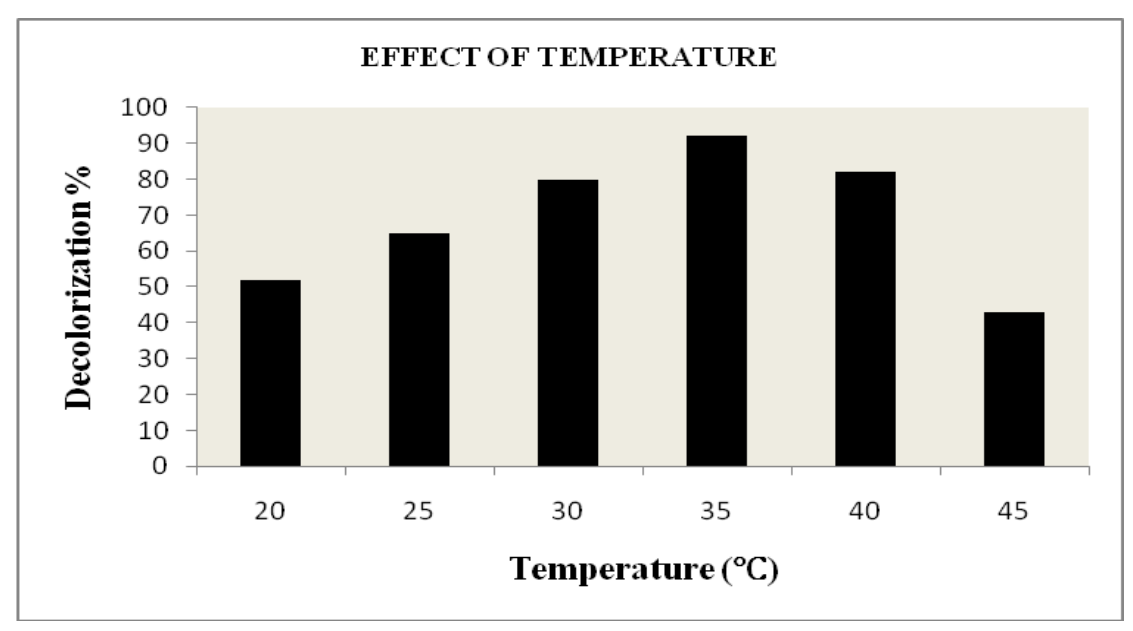


Fig.3 Effect of pH on the decolorization of Congo red by TVU-CR4

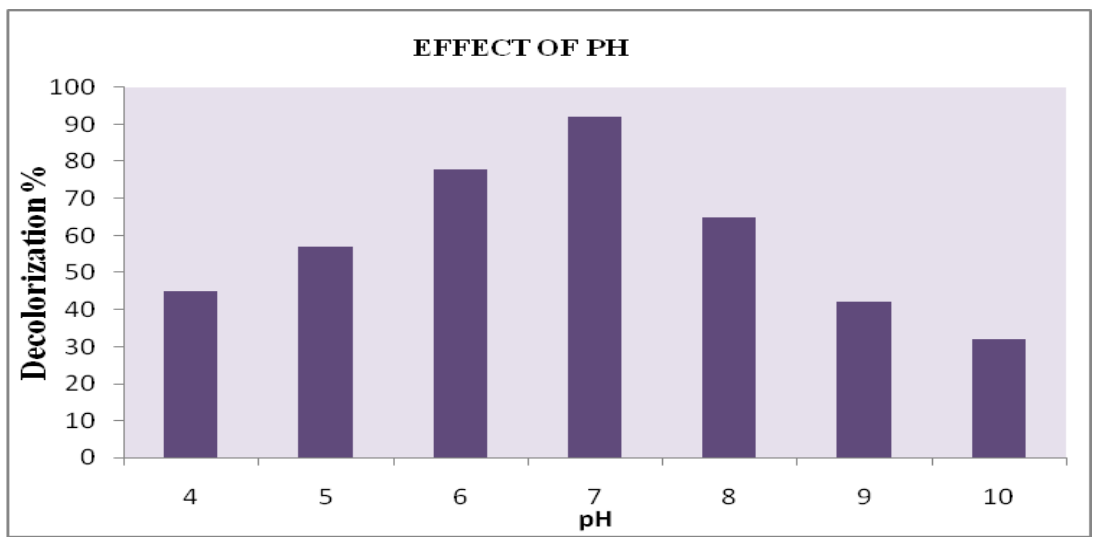

Fig.4 Effect of agitation speed on the decolorization of Congo red by TVU-CR4

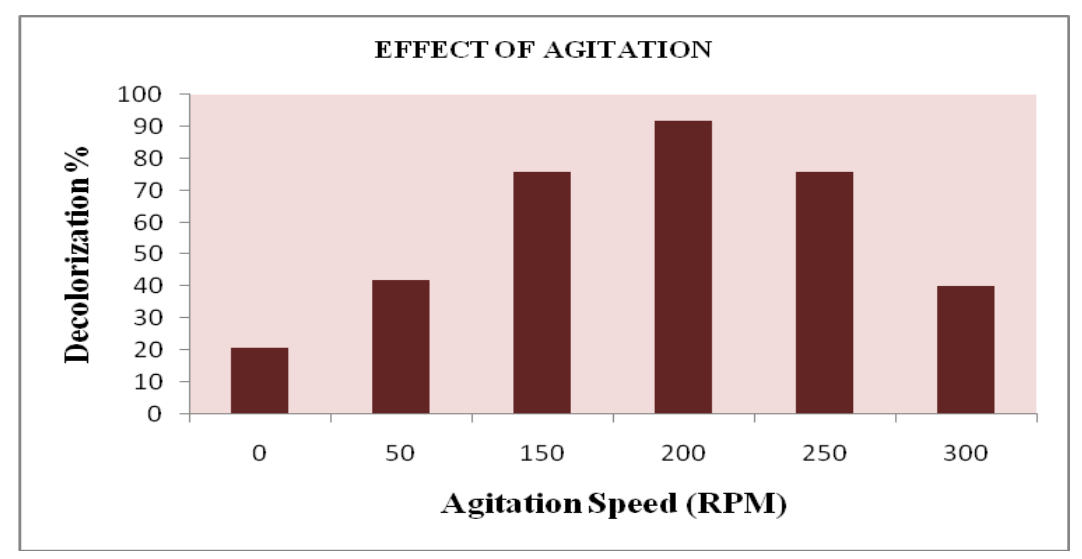

Fig.5 Effect of dye concentration on the decolorization of Congo red by TVU-CR4

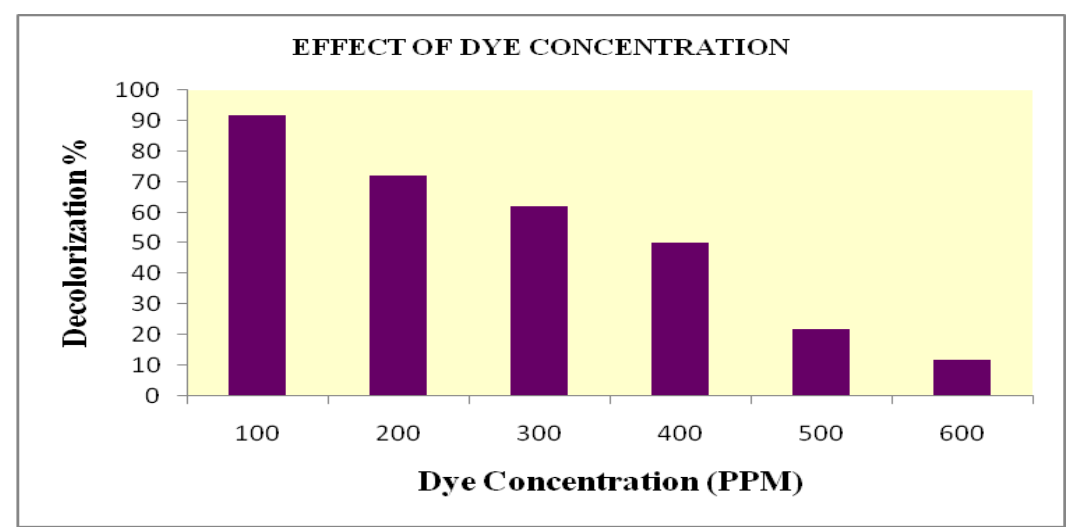

\section{Effect of dye concentration}

The influence of different dye concentrations $(200-1000 \mathrm{ppm})$ were studied on decolorization ability of the bacterial strain
TVU-CR4. The result shown in Fig 4 has revealed that the decolorization rate gradually decreased with the increase in initial dye concentration. As the dye concentration increased in the culture medium, a decline in 
color removal was attained. At high concentration (1000 ppm), decolorization ability of the bacterial strain was greatly suppressed by Congo red. Similar result was reported by Hemapriya et al., (2010). Reduction in the color removal efficiency might be attributed due to the toxicity of the dye to bacterial cells through inhibition of nucleic acid synthesis.

\section{Effect of agitation}

Aeration is an important parameter that influence the color removal efficiency of microbial cells. The dye decolorization ability of the bacterial strain TVU-CR4 was found to be greatly decreased with increases in agitation speeds. At $200 \mathrm{rpm}$, the decolorization ability of the bacterial consortium was greatly inhibited (Fig 5). Static conditions proved to be effective in maximizing decolorization percentage of the consortium. Azo dye decolorization by bacterial species is often initiated by enzymatic reduction mediated by azoreductase (Zimmermann et al., 1982). According to Chang and Lin (2000), azoreductase driven bacterial decolorization is normally inhibited in the presence of $\mathrm{O}_{2}$ primarily due to the competition in the oxidation of the reduced group as the electron receptor.

\section{Effect of carbon sources}

In a preliminary study, various soluble carbon sources were used to replace the original carbon source in the growth medium. Decolorization of Congo red was not constitutive; different levels of decolorization were found with different carbon sources. Among the various carbon sources tested, Glucose was found to be maximizing the decolorization efficiency of TVU-CR4 (Table 2). According to Khehra et al., (2005), the metabolism of glucose results in the production of reduced metabolites (NADH, FADH), which in turn leads to the enhanced decolorization capability.

\section{Effect of nitrogen sources}

The effect of various organic nitrogen sources (peptone, yeast extract, tryptone and beef extract) were investigated after $24 \mathrm{~h}$ of incubation. Among them, yeast extract was found to be the superior source in maximizing decolorizing ability of the consortium (Table 3). The metabolism of yeast extract is considered to be essential for the regeneration of NADH that acts as electron donor for the reduction of azo bonds (Carliell et al., 1995). Similar results were reported by Deng et al., (2008) and Vijayanand et al., (2017).

\section{Phytotoxicity study}

Phytotoxicity tests were performed in order to assess the toxicity of the untreated and treated Congo red dye samples. Macrotyloma uniflorum seeds treated with tap water showed $100 \%$ germination, the mean plumule length of $22 \pm 0.7 \mathrm{~cm}$ and the mean radical length of $8 \pm 0.6 \mathrm{~cm}$. $M$. uniflorum seeds treated with control sample (untreated dye) showed $60 \%$ germination, the mean plumule length of $12 \pm 0.4 \mathrm{~cm}$ and the mean radical length of $5 \pm 0.5 \mathrm{~cm}$. Interestingly, $M$. uniflorum seeds treated with test sample (treated dye) showed $100 \%$ germination, the mean plumule length of $21 \pm 0.5 \mathrm{~cm}$ and the mean radical length of $7.5 \pm 0.4 \mathrm{~cm}$ (Table 4). The above mentioned results clearly demonstrated the detoxification of Congo red by TVU-CR4. Similar results were recorded by many researchers (Parshetti et al., 2006; Saratale et al., 2009; Shyamala et al., 2014).

In conclusion, the concerted activities of TVU-CR4 were able to decolorize and degrade the textile azo dye Congo red with significant decolorization rate and required 
less incubation time under static condition. The idealized decolorization occurred at temperature of $35^{\circ} \mathrm{C}$ and $\mathrm{pH}$ 7. The decolorization was robust even under high concentration of Congo red. External carbon and nitrogen sources have enhanced the decolorization rate. The foregoing results suggest the potential of utilizing TVU-CR4 to degrade textile effluent containing synthetic textile dyes via; appropriate bioreactor operation

\section{References}

Aksu, Z., N.K.Kilic, S.Ertugrul and G.Donmez. (2007). Inhibitory effects of chromium (VI) and Remazol Black B on chromium (VI) and dye stuff removals by Trametes versicolor. Enz. Microbiol. Technol., 40:1167-1174.

Anjaneyulu, Y., N.S. Chary and D.S.S. Raj. (2005). Decolorization of industrial effluents - available methods and emerging technologies - A review. Rev. Environ. Sci. Biotechnol., 4:245-273.

Aswin Kumar, S., N. Arunagirinathan, S. Vijayanand, J. Hemapriya and Indra, V. 2017. Bioremediation and Detoxification of a Textile Azo Dye-Evans Blue by Bacterial Strain AKIP2. Int.J.Curr.Microbiol.App.Sci. 6(5): 26872694.

Carliell, C.M., S.J, Barclay, N.Naidoo, C.A.Buckley, D.A.Mulholland and E.Senior. (1995). Microbial decolorization of a reactive azo dye under anaerobic conditions. Water SA., 21:61-69.

Carvalho, M.C., C.Pereira, I.C. Goncalves, H.M.Pinheiro, A.R.Santos, A.Lopes and M.I.Ferra. (2008). Assessment of the biodegradability of a monosulfonated azo dye and aromatic amines. Int. Biodetor. Biodegrad., 62:96-103.

Cetin, D. and G.Donmez. (2006). Decolorization of reactive dyes by mixed cultures isolated from textile effluent under anaerobic conditions. Enz. Microbial Technol., 38:926-930.
Chang, J.S. and Y.C.Lin. (2000). Fed-batch bioreactor strategies for microbial decolorization of azo dye using a Pseudomonas luteola strain. Biotechnol. Prog., 16:979-985.

Deng, D., J.Guo, G.Zeng and G.Sun. (2008). Decolorization of anthraquinone, triphenylmethane and azo dyes by a new isolated Bacillus cereus strain DC11. Int. Biodetor. Biodegrad., 62:263-269.

Fan, L., S.Zhu, D.Liu and J.Ni. (2009). Decolorization of 1-amino-4bromoanthraquinone-2-sulfonic acid by a newly isolated strain of Sphingomonas herbicidovorans. Int. Biodetor. Biodegrad., 63:88-92.

Forss, J. and U. Welander. (2011). Biodegradation of azo and anthraquinone dyes in continuous systems. International Biodeter. Biodegrad., 65(1): 227-237.

Goncalves, I.M.C., A.Gomes, R.Bras, M.I.A. Ferra, M.T.P.Amorium and R.S.Porter. (2000). Biological treatment of effluent containing textile dyes. JSDC., 116: 393397.

Hemapriya, J and S.Vijayanand. (2013). Bioremediation of Structurally different textile dyes by a novel bacterial consortium. Int.J.Curr.Microbiol.Appl. Sci., 2(11):212- 226.

Hemapriya, J. and S.Vijayanand. (2014). EcoFriendly Bioremediation of a Triphenylmethane Dye by Textile Effluent Adapted Bacterial Strain VP-64. Int.J.Curr.Microbiol.Appl.Sci. 3(9): 983992.

Hemapriya, J., Rajesh Kannan and S.Vijayanand. (2010). Bacterial decolorization of textile azo dye Direct Red-28 under aerobic conditions. J.Pure Appl.Microbiol., 4(1):309-314.

Kalyani, D.C., A.A.Telke, R.S.Dhanve and J.P.Jadhav. (2009). Eco-friendly biodegradation and detoxification of Reactive Red-2 textile dye by newly isolated Pseudomonas sp. SUK1. J. Haz. Mat., 163:735-742.

Khehra, M.S., H.S.Saini, D.K.Sharma, B.S.Chadha and S.S.Chimni. (2005). 
Comparative studies on potential of consortium and constituent pure bacterial isolates to decolorize azo dyes. Water Res., 39:5135-5141.

Križanec, B. and A.M.L. Marechal. (2006). Dioxins and dioxin-like persistent organic pollutants in textiles and chemicals in the textile sector. Croatica Chemica Acta, 79:177- 186.

Olukanni, O.D., A.A.Osuntoki and G.O.Gbenle. (2006). Textile effluent biodegradation potentials of textile effluent-adapted and non-adapted bacteria. Afr. J. Biotechnol., 5(20):1980-1984.

Pandey, A., P.Singh and L.Iyengar. (2007). Bacterial decolorization and degradation of azo dyes. Int. Biodetor. Biodegrad., 59:73-84.

Parshetti, G., S.Kalme, G.Saratale and S.Govindwar. (2006). Biodegradation of Malachite Green by Kocuria rosea MTCC 1532. Acta Chim. Slov., 53:492- 498.

Rai, H., M. Bhattacharya, J. Singh, T.K. Bansal, P. Vats and U.C. Banerjee, U. (2005). Removal of Dyes from the Effluent of Textile and Dyestuff Manufacturing Industry: A Review of Emerging Techniques with Reference to Biological Treatment. Critical Rev. in Environ. Sci. Technol., 35: 219-238.

Saratale, G.D., S.D.Kalme and S.P.Govindwar. (2006). Decolorization of textile dyes by Aspergillus ochraceus (NCIM-1146). Ind. J. Biotechnol., 5:407- 410.
Saratale, R.G., G.D. Saratale, J.S. Chang and S.P. Govindwar. (2011). Bacterial decolorization and degradation of azo dyes: A review. J. Taiwan Ins. Chemical Engineers, 42(1): 138-157.

Saratale, R.G., G.D.Saratale, D.C.Kalyani, J.S.Chang and S.P.Govindwar. (2009). Enhanced decolorization and biodegradation of textile azo dye Scarlet $\mathrm{R}$ by using developed microbial consortiumGR. Bioresour. Technol., 100: 2493-2500.

Shyamala, A., J.Hemapriya, Kayeen Vadakkan and S.Vijayanand. (2014). Bioremediation of Methyl Orange, a Synthetic azo dye by a Halotolerant Bacterial strain. Int. J. Current Research and Academic Review. 2(8):373- 381.

Vijayanand, S. and J.Hemapriya. (2013). Bacterial bioremediation of textile azo dyes A Review. Ind. J. Appl. Res., 3(12): 480-482.

Vijayanand, S., Kayeen Vadakkan and Hemapriya, J. 2017. Ecofriendly Bioremediation of Acid Orange - An Electron Deficient Xenobiotic Chromogen by Haloalkaliphilic Bacterial Consortium TVU- AO 64. Int.J.Curr.Microbiol.App.Sci., 6(4): 956963.

Zimmermann, T., H.G.Kulla and T.Leisinger. (1982). Properties of purified Orange II azoreductase, the enzyme initiating azo dye degradation by Pseudomonas KF46. Eur. J. Biochem., 129:197-203.

\section{How to cite this article:}

Barathi, A., J. Hemapriya, Ramya Gunasekaran, Kayeen vadakkan, A. Shyamala, Aswini Ravi and Vijayanand, S. 2020. Biodegradation and Detoxification of Congo Red by Intuitive Bacterial Strain TVU-CR4. Int.J.Curr.Microbiol.App.Sci. 9(11): 3772-3781. doi: https://doi.org/10.20546/ijcmas.2020.911.453 